Article

\title{
Local Energy Communities and Distributed Generation: Contrasting Perspectives, and Inevitable Policy Trade-Offs, beyond the Apparent Global Consensus
}

\author{
Stefano Moroni ${ }^{1}\left(\mathbb{D}\right.$, Valentina Antoniucci ${ }^{2}(\mathbb{C})$ and Adriano Bisello ${ }^{3, *}$ (i) \\ 1 Department of Architecture and Urban Studies, Polytechnic University of Milan, via Bonardi 3, \\ 20133 Milano, Italy; stefano.moroni@polimi.it \\ 2 Department of Civil, Environmental and Architectural Engineering, University of Padua, via Venezia 1, \\ 35151 Padova, Italy; valentina.antoniucci@unipd.it \\ 3 Institute for Renewable Energy, Eurac Research, Viale Druso 1, 39100 Bolzano, Italy \\ * Correspondence: adriano.bisello@eurac.edu
}

Received: 27 May 2019; Accepted: 23 June 2019; Published: 25 June 2019

check for updates

\begin{abstract}
Although a certain degree of consensus seems to pervade the ideas of "distributed energy systems" and "energy communities", in truth, diverse views are involved. This article aims to shed light on the variety of interpretations of these two concepts. In particular, the article critically considers the answers to the following four questions: What exactly is meant by "distributed" in the expression "distributed energy generation"? Why is distributed generation (ethically) desirable? Why should people consider it a positive idea that "communities" — and not individuals or families—are invited to manage distributed generation systems? Lastly, can energy communities be considered different from standard state intervention and from market systems? Clearly defining these questions helps in emphasising crucial differences, and it is an important step toward achieving a critical understanding. The conclusion is that there is no single interpretation for either the idea of distributed energy or that of energy communities. Shifting emphasis from one feature to another can drastically affect what policies are required to foster the creation of such communities and of a distributed energy production scenario.
\end{abstract}

Keywords: energy transition; energy community; distributed energy; renewable energy; prosumer

\section{Introduction: An Apparently Unitary Front}

The themes of distributed generation and energy communities are acquiring an increasingly important role, both in scientific literature and in the construction of scenarios and policies, as in the EU Framework 2030 [1] and the UN 2030 Agenda for Sustainable Development [2]. As St. Denis and Parker [3] (p. 2088) observe, "Energy has traditionally been managed at the level of the individual customer [ ... ]. A recent trend is for communities to create plans to directly manage their energy systems. These local initiatives are heralded as precursors to a future network of distributed generation where large central generating stations are replaced with many dispersed and smaller generation sources" (see also Klein and Coffey [4]). In this scenario, consumers are supposed to become electricity producers as well as consumers, that is, not merely passive consumers but active prosumers $[5,6]$. Prosumers are among the core topics of the so-called EU Winter package published in November 2016 by the European Commission. It includes proposals to favour the transition to a "clean energy economy" by amending existing energy market rules, recognising new technological and digital innovations, revising climate-energy legislation and introducing new supporting measures [7]. In particular, the 
EU recognises that "local energy communities can be an efficient way of managing energy at a local community level by consuming the electricity they generate either directly for power or for (district) heating and cooling, with or without a connection to distribution systems" [8] (p. 4). The EU also recognises that legislative, more than technical, barriers currently limit their operation: "To ensure that such initiatives can freely develop, the new market design requires Member States to put in place appropriate legal frameworks to enable their activities" [8] (p. 4).

The phenomenon of distributed local energy management is already particularly evident in some countries; for example, in the Netherlands, more than 500 initiatives aim to convert local communities into self-sufficient, low-carbon settlements. Also, in Germany, there are more than 900 energy cooperatives involved in the management of distributed energy production [9]. A recent European Project named REScoop 20-20-20 [10] has established the European federation of renewable energy cooperatives, accounting so far for 1250 European energy cooperatives: they gather about one million citizens actively involved in the energy transition.

These initiatives often create the false impression of a unitary front that can, for example, be comprised in the so-called '3D paradigm': decarbonization, decentralization and digitalization of energy systems [11]. However, that is not the case, as becomes apparent when we dig deeper. In other words, although a certain degree of consensus seems to pervade the logic of renewable distributed energy systems, diverse rationales are in fact involved [12]. The same applies to energy communities, a concept often considered as univocal, but that hides in reality a great variety of interpretations and meanings (see e.g. [9,13-20]). After a long period of largely uncritical acceptance of the idea of energy communities, works that invoke the need for a stronger critical approach in this regard are emerging $([21,22])$.

From this perspective, the article focuses on four fundamental questions (two of them regarding the idea of distributed generation itself and the other two the meaning and role of energy communities), assuming that the answers to them are far from univocal (Section 2), and that from different answers derive deeply different policy implications (legislative, fiscal, infrastructural) (Section 3). The concluding remarks emphasise irreducible differences and unavoidable trade-offs in these fields (Section 4).

In methodological terms, the article is based on an extended literature review and on the exploration of some case studies. The literature review started by detecting the expressions "energy communities" and "distributed generation AND energy" in articles and reviews published in the last decade. At the moment of writing this article-June 2019-and taking into consideration title, abstract and key words, Scopus database reports 207 results in the former case and 3600 results in the latter. As Figure 1 shows, both topics exhibit a clear trend of increasing interest by scholars.

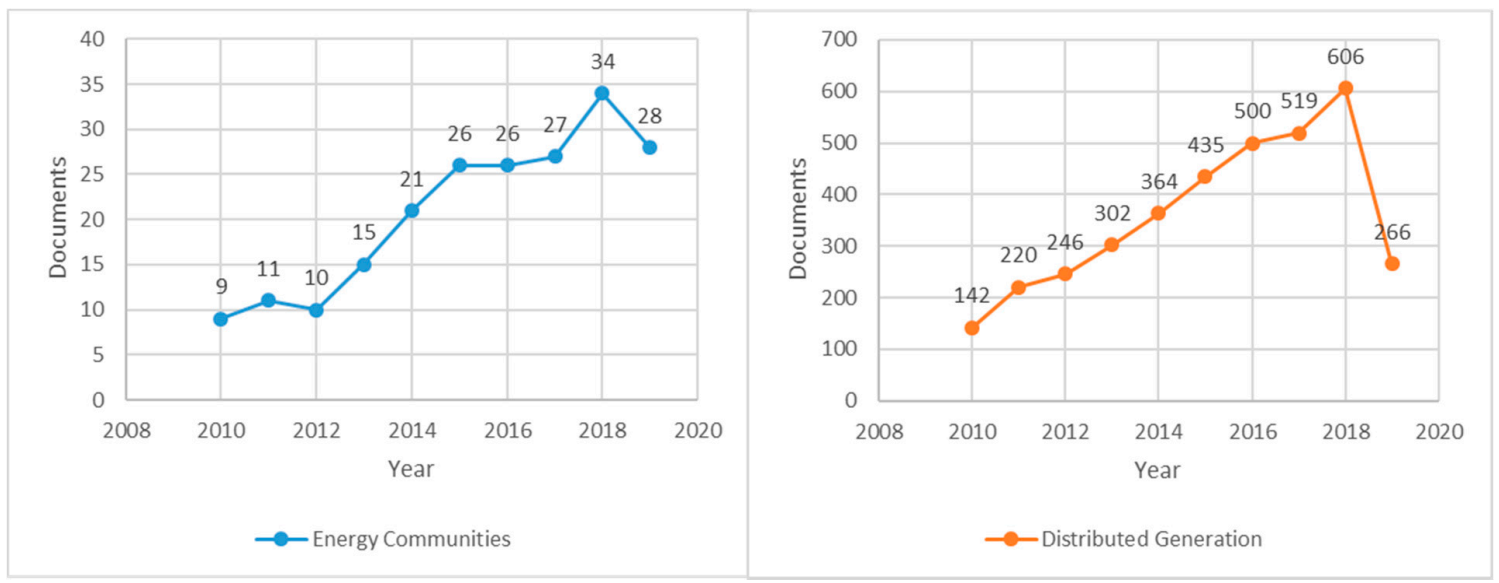

Figure 1. Articles and reviews per year.

The two expressions were subsequently combined with the terms "values", "motivations", "barriers", "policies", "incentives". The literature review findings were finally compared with certain 
case studies. The case studies investigated were: in Italy, Abbassa la bolletta, Retenergie, Comunità Solare di Casalecchio di Reno, SEV/Südtiroler Energieverband; in Germany, Solardachbörse; in the United Kingdom, Gorran High Lanes; in Denmark, the multiple experiences related to Samsø Island; in the US, the Highlands Ranch Community Association and the Kauai Island Utility Cooperative. The case studies were explored by means of official documents, on-the-spot investigations, meetings and interviews with key informants, texts and articles, official websites [23-31]. The case studies are not extensively reported here because they were only used to identify and test problems and differences (they are presented in detail in Moroni et al. [19]). In what follows, they will be recalled and briefly described when useful for exemplifying some questions or positions.

Both the literature review and the case studies have in fact here only an exclusively instrumental relevance. The principal intention of the article is to conduct a critical-theoretical discussion of certain issues rather than furnish entirely new empirical data. Our background idea is that we already have a great deal of empirical information on certain phenomena (e.g., energy communities' projects throughout Europe) and on certain technological devices (i.e., small size plants and systems for distributed generation, such as photovoltaic panels, microwind turbines and micro smart grids); what we still lack is a more critical perspective on them (i.e., on their meaning and role).

\section{Four Crucial Questions}

The first two questions that we will consider concern the idea of distributed generation itself (Sections 2.1 and 2.2). The other two concern the role of energy communities (Sections 2.3 and 2.4). These four questions have been chosen because they help in emphasising certain crucial differences. In our opinion, clearly defining these four kinds of questions is a first and helpful step toward achieving a critical understanding of the issues under discussion.

\subsection{First Question: Generic Decentralization Vs Polycentric Self-Governance}

The first relevant question is this: In what sense does the term "distributed" denote the production of energy in a distributed energy production scenario?

\subsubsection{Decentralization}

The simplest and most basic answer is that generation is distributed because the devices to produce energy are small in size and distributed throughout the territory. In short, they are physically closer to consumers. The crucial point here, therefore, is that small energy plants are on site. Energy is therefore not yet produced in large-scale plants far from the final consumers.

\subsubsection{Polycentric Governance}

A more radical response-which includes but goes beyond the first-is that the generation is distributed because the ownership of small plants, and the decision-making power concerning the production and distribution of energy itself, pass to a plurality of private entities. In other words, distributed energy involves much more than merely situating smaller energy units close to consumers.

A polycentric energy system may therefore be something more than a merely decentralised energy system. Indeed, 'polycentrism' does not simply mean that energy production units are decentralised (and not centralised); it also means that they are under numerous, different and autonomous, forms of private local management [32]. The crucial point here is therefore self-governance.

\subsubsection{Final Remarks}

The two options mentioned are obviously not necessarily in contrast with each other. It is more a matter of emphasis. And yet, focusing mainly on the first aspect or predominantly on the second completely changes the perspective. 
One can identify two different conceptualisations of localism. In the first case, the focus is on the physical geography of change; in the second, it is on the geography of ownership (and on the geography of decision making).

In particular, the second concept emphasises that the ways in which small plants are managed-their activation or shutdown, their maintenance, local accumulation and consumption, etc.-are and will increasingly be beyond the control of large operators, networks and large traditional systems. Today there are not only prosumers but also prosumagers, who produce, consume and manage their own energy because, thanks to innovative storage systems, they can easily decide to use their excess production at a subsequent time [33].

\subsection{Second Question: Reducing Environmental Impact vs. Enlarging Freedom}

A second question is this: Why is distributed generation (ethically) desirable?

\subsubsection{Environmental Concerns}

Akorede et al. [34], among others, say distributed generation is desirable primarily for environmental reasons (in part, it directly reduces environmental impacts; in part, it has an indirect effect in this regard by reducing the waste of energy). It would in itself guarantee at least the following four advantages.

First, it would reduce transmission and distribution losses produced by current centralised energy production systems in need of long transmission and distribution networks [35]. Losses vary widely around the world: in developing countries their values can reach more than $30 \%$; loss ratios in developed countries are expected to range between $6 \%$ and $8 \%$ [36] (p. 1124).

Second, it would make it possible to remedy distribution inefficiencies and alleviate utility peak demand problems [37]. Distribution inefficiencies are a combination of technical and nontechnical problems, such as systematic errors in metering, settlements or billing, and even theft [38] (p. 3159). Traditional grids may hinder "fixed" technical losses due to the peak power demand, while, for instance, (micro) smart grids prevent inefficiencies of this kind due to the response devices.

Third, distributed generation would reduce electromagnetic radiation due to long high-voltage transmission lines. Negative effects of electromagnetic radiation on human health (related, for instance, to structures and cables of high-power grids) have been detected. As Tong et al. [39] (p. 253) report, according to current research, "the main effects of strong electric field on human body include the weakening of endocrine system, cardiovascular system and central nervous system". Note that growing urban density, mostly in China and the Far East, increases the chances of high buildings being exposed to high-voltage cables. The pressure of energy demand expands the need for long-distance transmission lines, such as the $1373 \mathrm{~km} 800 \mathrm{kV}$ transmission line from Yunnan to Guandong in China [40].

Fourth, distributed generation would help to do away with the traditional large power plants and long transmission lines typical of the traditional centralised energy system, which in themselves spoil the environment and the landscape [41-44].

Certainly, the advantages would be even greater in environmental terms if distributed generation was based on renewable sources. In this regard, we can observe that decentralised distributed energy is intrinsically based mainly on local resources [45]. It is therefore more prone to use renewable resources [46]. In fact, many renewable sources (sun, wind, etc.) are per se site-specific. The use of renewable sources would reduce the emission of carbon dioxide $\left(\mathrm{CO}_{2}\right)$ and other pollutants in amounts close to $100 \%$, compared to fossil-fuel-based systems.

\subsubsection{Freedom}

According to other scholars [47], distributed generation is not, mainly, a question of environmental compatibility. It is instead desirable above all because it increases the freedom, autonomy and independence of individuals and groups. In short: "The primary reasons individuals might wish to supply all of their own power centre around the desire for greater autonomy" [48] (p. 526). 
To date, citizens have in fact been forced to link up to large centralised public networks. In the US, as in other countries, it is actually illegal to disconnect from the utility system in many localities. Several examples of living off-grid being prosecuted, or in any case not considered legal, are reported by the media [49-52].

From a different perspective, citizens should have greater freedom in choosing the technological solutions that they prefer, and they should enjoy a broad self-sufficiency $[47,53]$. As Lowi and Crews [47] (p. 162) write, although few "favor full-scale decontrol, such a policy is, in our assessment, the most desirable one. Full-scale decontrol would mean the elimination of exclusive territorial franchises. It would mean the de-regimentation and de-politicization of distribution as well as generation".

It is no coincidence that, in this regard, the possibility of islanding private initiatives is often underlined (on off-grid communities' opportunities and problems, see [54,55]). What is highlighted in this case is that there are no reasons for the government to intervene if there are technically viable private solutions [56].

\subsubsection{Final Remarks}

These two options also are not (necessarily) conflicting. And yet, if the emphasis is on the first perspective, a certain reduction of freedom will always be desirable to diminish environmental impacts.

On the other hand, if the emphasis is on freedom, reduction of environmental impact will be a secondary problem to address. This point is evident in Lowi and Crews [47] who, only after having recommended distributed generation based on private contractual communities as desirable in terms of freedom, concern themselves with how to reduce environmental impacts. They write: "The resources used for generation and distribution would be deemed the private property of the owners, and freedom of contract would be granted. [ ... ] Problems of emissions, noise, vibrations, and risk could be treated by tort action, negotiation, or, especially in the case of emissions, by simple and fair pollution charges" [47] (p. 162).

\subsection{Third Question: The Instrumental Value of Communities vs. Their Intrinsic Value}

A third crucial question is this: Why should people find it desirable to be "communities" and not isolated individuals/households managing distributed production? In fact, the idea of distributed generation does not entail any particular role for organized groups; this role depends on further considerations.

\subsubsection{The Instrumental Value of Communities}

According to some scholars [57], organizing energy communities is functionally advantageous, for four main reasons.

Firstly, it reduces direct investment and operation and maintenance costs. The community guarantees microeconomies of scale, such as lower costs for the plants and infrastructures [58], because they are shared among a group of members, as well as make it possible to use smart microgrids to manage energy flows better $[59,60]$. When built and employed at the community level, energy facilities and services allow for economies of scale that their owners could not achieve by acting individually [61] (p. 166). In short, if someone chooses to invest in renewable energy in cooperation with others, then he/she can presumably "afford a greater and more expensive technology for smaller input, since joint investment reduces the costs" [62] (p. 43).

Secondly, operating as a community reduces certain transaction costs, for example, in terms of the time, effort and so forth, needed to start community activities and become organized.

Thirdly, acting as a community reduces the risks of investments. The entire financial operation can be shared among a variety of subjects. Sharing the risks together with others (i.e., risks connected with changes in regulations, failure of a certain technology, modifications of market conditions that can lead to financial loss) can induce individuals to procure certain technological devices jointly [62] (p. 43). "In the course of collective action, the risk and also its consequences are distributed among all 
the group members, which renders major investment possible and allows for taking higher risks than in case of individual action" [62] (p. 43).

Fourthly, acting in a group makes it possible to build integrated systems that optimize local production and consumption. This point is aptly underscored by Koirala et al. [9]. Energy-efficient types of consumption are possible only through the combination of several individuals (e.g., households) in a community of evolved prosumers. For this purpose, technologies such as the Regalgrid® platform, created by an Italian start-up, and that of Ectogrid, of the German energy utility E-O.N, have been developed. Regalgrid $囚 m a k e s$ it possible to digitally connect different elements of the system in order to maximise the electricity self-consumption of a community of users. This can be achieved through a cloud-based software integrated into a device called SNOCU (Smart Node Control Unit), which can be connected to inverters, batteries and smart metres that are already available on the market [63]. Interestingly, despite being effective and profitable, this solution is not fully applicable in the same country where it has been developed; in Italy, there is not yet legislation that regulates energy sharing amongst users with different points of delivery. Sharing energy through the traditional utilities metres is not possible for small prosumers, and it would mean the application of the highest rate of charges and excise duties, making energy sharing amongst prosumers not at all convenient. The second example refers to the EctogridTM system, which, by connecting different buildings, enables "energy needs (heating or cooling) to be matched by someone else's opposite energy needs. This reduces the total amount of energy needed" at the neighbourhood, district or city scale and "makes it possible to decrease both pollution and the energy consumption" [64].

From this first perspective, energy communities have a predominantly instrumental value. There is nothing inherently desirable in a group if not the benefits that can be derived from being part of it. In this case we may talk about communities of interest.

Initiatives such as Abbassa la bolletta (Italy) and Solardachbörse (Germany) are examples in this regard. The Abbassa la bolletta initiative (sponsored by the nonprofit association "Altroconsumo" since 2013) has enabled consumers throughout Italy to join together in a purchasing group for electrical energy and methane gas (for mainly domestic use), reducing their costs. Solardachbörse is a German online portal fostering the match between demand and supply through the building of a virtual community enabling people to rent out their roofs for photovoltaic plants. Note that both are examples of non-place-based communities [19]; members do not directly and personally meet in principle.

\subsubsection{The Intrinsic Value of Communities}

According to other scholars [65], the crucial point is that there is something fundamental in the fact of being joined together in a community that makes communities desirable (for example, the construction and maintenance of new social bonds, the consolidation of mutual trust, etc.). As van der Horst [65] (p. 180) notes, "a warm community [ ... ] creates more and better opportunities for community activities. These activities may [in turn] help to create a stronger sense of community and thus build and strengthen social capital".

A substantial part of the literature is focused on this point. In this case, energy communities have a kind of intrinsic value. It is the existence of the group and of collective bonds that gives value to the experiences of the individual members (on the difference between the instrumental and intrinsic value of energy communities, see [66]).

In this case, we may talk about communities of identities, which are sometimes also called civic energy communities. As reported by Herbes et al. [67], following an extensive survey on German energy cooperatives, it appears that often alongside energy-focused activities (e.g., production, distribution, marketing, financing), cooperatives operate or intend to evolve towards other non-energy-focused activities (e.g., telecommunication, mobility service, village shop) maintaining their ethical foundations, that is, the value of social inclusion and action that inspires their core activities.

Also, Süsser and Kannen [68] (p. 568), in their study on perceptions and assessments of community transition in Germany, reported that some of the interviewed members of energy communities "reveal 
that the development of renewables has increased the communal spirit and cohesiveness between the community members". They continue: "Our research revealed high relevance of community-based renewables due to the diverse nature of social benefits generated. These benefits include community spirit and cohesiveness [... ]. We found a strong identification for a common interest in and working together because of renewables" [68] (p. 573).

Research by Hicks and Ison [20] reports various cases of communities based mainly on social motivations, such as the Hepburn Wind community energy (i.e., the owner and operator of the first community-owned wind farm in Australia. This 4.1 MW wind farm hosts two turbines that produce enough energy for 2000 homes [69]). Hicks and Ison state that this community values "social motivations highly and reported them as both motivations and benefits of their projects" [20].

A similar case, the local energy community project of Gamblesby village in Great Britain, is discussed in depth by Walker et al. [70]. The Gamblesby case study demonstrates that "ideal' cohesive communities with reservoirs of 'thick trust' [ ... ] do exist"; in this case, there is evidence that even the process adopted "was able to contribute to the further building of social capital" ([70] p. 2662; in general, see on this issue also [71,72]).

A significant dimension of social cohesion is also exemplified by the set of initiatives that have been developed on Samsø Island in Denmark. In this case, we have a multiplicity of associations and organisations working together to achieve shared objectives such as local development and energy transition. The Samsø project started in 1997. Samsø became energy-independent in 2005. The project mobilised a large part of the island's population and created a cohesive social environment.

Seen from this perspective, the "simple" communities of interest are not considered real communities, but "meta-individual" experiences [73]. In particular, Aiken writes that [74] (p. 90): "Projects such as those that seek to gather together groups of individuals who want to install solar panels, in order to gain economies of scale discount on price, fall short of what is meant by 'community' here; that would be an individual approach, albeit on a larger scale. Community can be seen as a scale up from individual, but it is also a different category from other 'meta-individual' concepts, such as the 'group'".

\subsubsection{Final Remarks}

In conclusion, the two options are not - even in this case - necessarily and intrinsically in contrast [75], though they could be. Some operators can exclusively concern themselves with reducing costs (and other functional advantages) without giving any direct and particular weight to strong social bonds, while others give more emphasis to the collective identity and cohesion and less to mere cost reduction or other functional benefits.

\subsection{Fourth Question: Specific Nonprofit Intentions vs. Generic Voluntariness}

The fourth question is as follows: Should energy "communities" be considered as something different both from the intervention of the state and from the operation of the market?

\subsubsection{Nonprofit Motivations}

According to some, yes; they are a sort of "third way". In this case, the nonprofit nature of many energy communities is emphatically underlined. The difference between profit-seeking initiatives and non-profit-oriented ones in the renewable sector is, for instance, underlined in Hatzl et al. [76] and Seyfang and Smith [77]. In a study on energy communities, Frantzeskaki et al. [78] (p. 104) write: "Several scholars have emphasised that the main contribution of the Third Sector is that it provides a diversity of alternatives to public or private sector". The crucial point for those who adopt this first perspective is to develop a new civic culture. 


\subsubsection{Voluntariness}

According to others, an energy community would simply be one of many possible forms of voluntary private action [79]. In this case, it does not matter that energy communities are nonprofit or for-profit, or a mix of them. From this perspective, the distinction between for-profit and nonprofit itself is not as important as often maintained. In both cases, what really matters is that there is voluntary action within civil society [79].

The crucial point here is to develop a new entrepreneurial culture (individual and group). It should be noted that forms of "social enterprise" $[65,80,81]$ appear in this approach as totally natural, and do not need any new or specific theoretical framework.

A recent and interesting example, showing how the idea of for-profit entities and that of nonprofit entities are sometimes even difficult to separate, is the partnership between Kauai Island Utility Cooperative (KIUC) and Tesla Industry [31]. In 2016, Tesla began to develop a large battery farm solar array on Kauai Island (western Hawaii Islands). The plant consists of an array of 55,000 individual photovoltaic panels and storage battery packs (272 Tesla Powerpack lithium-ion with $52 \mathrm{MWh}$ of storage capacity), and occupies 50 acres of land near the already existing power station of KIUC's Kapaia. The agreement between KIUC and Tesla for twenty years guarantees KIUC a fixed electricity purchase price. The stability of energy supply from renewable sources prevents the potential increase in imports of coal or oil to fuel power plants, which may be more expensive for a population far from the mainland. This solution, therefore, increases the independence of the community and secures the energy supply. The plant's installation and its operation and management are cost-effective in themselves, independently from fiscal incentives. The plant's cost is $\$ 12$ million, given $30 \%$ of the tax credit, and the operation and management costs amount to $\$ 425,000$ per year. Consequently, the Kauai project's Internal Rate of Return is $6.2 \%$ (slightly better than the $6 \%$ average rate used by solar industries in discounted cash flow analysis). As said, this example in some way (according to those who focus more on the voluntariness of certain initiatives than on their motivations) demonstrates the pointlessness of the nonprofit vs. profit opposition. Here, the nonprofit entity KIUC reached a twenty-year agreement with a business company, Tesla, that guaranteed the economic sustainability of the project, without compromising the mission and scope for either of them.

\subsubsection{Final Remarks}

These two points of view seem to contrast more strongly than the previous ones. In the first case, it would seem that nonprofit is a salient and necessary characteristic. It is the motive behind the action that is the crucial element.

On the contrary, in the second example, the focus is on the voluntariness of the action. It is therefore the nature (and not so much the motive) of the action that counts.

\section{Discussion and Policy Implications}

The ongoing energy transition, resulting from technological innovation and concerns about climate-environmental implications, stresses the urgent need to redesign our energy systems, taking into account distributed energy production and the decisive, potential role of energy communities. As has been pointed out, however, neither the idea of distributed energy nor the idea of energy communities has a univocal interpretation. Moreover, the former idea does not imply the latter. Furthermore, the use of renewable sources is not implicit in either of the two. There can in fact be distributed energy (individual-based or community-based) with both renewable and nonrenewable sources [82,83]. It is therefore necessary to have a clearer view of the complexity of such phenomena. As Zibelman [84] notes, while policy makers cannot mandate innovation, they should do their best not to hinder it (compare with Moroni [85]). However, placing emphasis on some aspects rather than on others significantly changes both the organisational form that is preferable for a community, and the 
type of policies that can be introduced to make distributed energy production possible and encouraged (i.e., some measures could favour some social arrangements but not others [86-89]).

\subsection{First Question}

Let us return to the first question addressed above, which focused on the relationships between technology and organization.

If, for instance, the idea of distributed generation is focused only on the decentralisation of small plants, then local public bodies can also be owners and have control over them. Various types of consortia or partnerships between public bodies and private bodies are in this case possible, as in the example of the 300 small cooperatives and municipally owned companies producing energy in the Alpine region of South Tyrol, in Italy. It is no coincidence that we often speak here of local districts. (On the innovative role that local municipalities may have in the transition to a low-carbon society, see [90-93].)

If we concentrate on polycentrism, the idea will rather be to entrust the ownership and control of the plants to a plurality of private subjects. Consortia or partnerships with public bodies are not considered desirable in this light. In this case, energy communities and private contractual communities $[94,95]$ tend to coincide.

Legislative and political reforms which favour one or the other view can be very different and not necessarily compatible. A substantial difference will be introduced by any restrictions on the type of parties authorized to operate in the field of renewable energy, and by any requirements for trading or sharing energy. As Hicks and Ison [20] (p. 528) point out, defining the legitimate group of individuals that make up the community is a crucial element of energy communities initiatives. As they observe: "There may be no single answer to the question of who constitutes an appropriate actor in CRE [Community Renewable Energy projects], but it is imperative that [ ... ] policy makers [ ... ] make informed and conscious decisions when drawing the boundaries around CRE, as these decisions affect the ways that CRE projects are scaled, owned, financed, developed and regulated" [20] (p. 524).

In both situations, uncovering the social and behavioural levers in the surrounding context also becomes crucial to variously support the uptake of innovative initiatives [96].

\subsection{Second Question}

Something similar applies to the second issue mentioned above: the possible divergence between environmental compatibility and individual freedom.

If distributed generation seems desirable mainly for environmental reasons, it will be necessary to put in place economic support policies to favour the adoption of renewable-based systems. We can for instance cite the experiences of several European countries with various forms of feed-in tariffs in favour of small plants based on renewable sources (widely documented in terms of effectiveness and stimulus $[97,98])$.

In this case, to avoid distorted effects, particular attention should be paid to the preventive definition of environmental and landscape compatibility criteria. Also to be included are long-term strategies that draw an economic trajectory clear for the sector (aimed at consolidating the existing economic situation and not to create temporary "bubbles"). In Italy, a quite lucrative feed-in tariff scheme for photovoltaic electricity was implemented in the last decade without adequate regional energy planning tools. It resulted in a "photovoltaic rush" between 2005 and 2013, also attracting foreign investors in the construction of utility scale photovoltaic fields in questionable locations. From less than $90 \mathrm{MW}$ of installed capacity in 2007 to $18.5 \mathrm{GW}$ in 2014, Italy ranked fourth in the world in terms of cumulative installed photovoltaic capacity in 2014 [99]. This feed-in-tariff is no longer in use. Today, only small scale domestic photovoltaic plants—up to 20kW-are supported by the government, allowing the owner to recover up to $50 \%$ of investment costs in 10 years thanks to a tax deduction (see the Italian National law no. 205 of 2017). 
On the other hand, if distributed generation seems to be beneficial primarily because it increases freedom, independence and autonomy, changes in the legislative framework will be necessary to broaden the space of action of individuals and groups (in many countries, such as Italy and Spain, there are still many constraints on energy production, freedom of association, freedom to contract and the freedom to sell and buy services). This would be desirable even regardless of energy source. In particular, policies should allow digital accounting systems such as net energy metring and make it possible to transact energy and use peer-to-peer trading, including the use of bitcoin and blockchain technologies [11].

\subsection{Third Question}

A third contrast considered above is the one between interests for efficiency and focus on social bonds.

The important point is that, if we consider energy communities as desirable for mainly instrumental reasons (e.g., reducing costs and risks), then any type of association and organization that brings together a group of members will be acceptable (also non-place-based, virtual communities). Accordingly, it is desirable to encourage the creation of any entity that combines the energy flows, the distributed systems and the accumulation systems of large groups of users, also aggregated into virtual power plants. Moreover, the legislation should maximise functional advantages by granting more room to those devices that provide innovative energy services, and also, for instance, electric vehicles connected to the grid (V2G) able to both store and release energy according to the needs of the system.

If we consider energy communities important for reasons that are mainly intrinsic-creating identity and collective cohesion-we will tend to favour some forms of aggregation over others. It is not without reason that those who adopt this second perspective tend to conceive cooperatives as the main form of energy community [100]. These same people affirm that cooperatives need support in terms of policies and incentives, maintaining and reinforcing local trust relationships and social capital.

\subsection{Fourth Question}

With reference to the fourth case analysed, it clearly makes a substantial difference if nonprofit is the central focus or instead if voluntariness is considered the crucial aspect.

On the first view, it would be important to create policies to promote the third sector and expand its role. In some countries, nonprofit community energy projects are eligible for particular grant support: see for example the Nonprofit Facility Energy Efficiency Grants of the Energy Outreach Colorado, addressed to organizations owning facilities that serve low-income populations [101], and the Community Innovations Grant Program (Connecticut). In the USA, Indiana, Pennsylvania, Wisconsin and Michigan also finance similar programs [102]. A study on the early stages of UK government policies in favour of renewable energy highlighted how "small-scale profit-based projects are not eligible for grants", while "nonprofit domestic and community-based projects have broad opportunities for government capital support" [86] (p. 1202).

On the second view, legislative reforms will be required to increase the space for voluntary actions, whatever they may be, without any penalisation in the case of profit or premium in the case of nonprofit activities. If policies stress this latter view, their main objective is to develop new business models for the energy market, regardless of the purpose that they intend to pursue.

\section{Conclusions: Irreducible Differences and Inevitable Trade-Offs}

The themes of distributed generation and energy communities seem at first glance to have created a global consensus among scholars and politicians. The reality is that we often underestimate profound differences in how we interpret and evaluate these two issues. The foregoing discussion, summarized in Table 1, shows how wide those differences can be. 
Table 1. Issues, questions, perspectives, policies.

\begin{tabular}{|c|c|c|c|}
\hline Issues & Questions & Perspectives & Policies \\
\hline \multirow{4}{*}{ 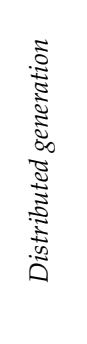 } & \multirow{2}{*}{$\begin{array}{l}\text { 1. In what sense does 'distributed' } \\
\text { denote the production of energy in } \\
\text { a distributed energy } \\
\text { production scenario? }\end{array}$} & $\begin{array}{l}\text { Decentralisation (i.e., on-site } \\
\text { production) }\end{array}$ & $\begin{array}{l}\text { Favour local developments in } \\
\text { general (also involving local } \\
\text { governments and agencies) }\end{array}$ \\
\hline & & $\begin{array}{l}\text { Polycentrism (i.e., ownership and } \\
\text { decision-making power in the hands } \\
\text { of a plurality of private entities) }\end{array}$ & $\begin{array}{l}\text { Favour local private } \\
\text { arrangements specifically }\end{array}$ \\
\hline & \multirow{2}{*}{$\begin{array}{l}\text { 2. Why is distributed generation } \\
\text { (ethically) desirable? }\end{array}$} & Environmental concerns & $\begin{array}{l}\text { Favour access to (and use of) } \\
\text { renewable-based small plants }\end{array}$ \\
\hline & & Freedom, independence, autonomy & Increase freedom of choice \\
\hline \multirow{4}{*}{ 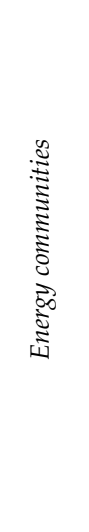 } & \multirow{2}{*}{$\begin{array}{l}\text { 3. Why should people find it } \\
\text { desirable to be "communities" } \\
\text { and not individuals/households } \\
\text { managing distributed production? }\end{array}$} & $\begin{array}{l}\text { Communities' instrumental value (i.e., } \\
\text { "communities of interests") }\end{array}$ & $\begin{array}{c}\text { Favour any kind of association } \\
\text { or organization (also } \\
\text { non-place-based, even } \\
\text { totally virtual) } \\
\end{array}$ \\
\hline & & $\begin{array}{l}\text { Intrinsic value of communities (i.e., } \\
\text { "communities of identities") }\end{array}$ & $\begin{array}{c}\text { Favour particular kinds of } \\
\text { associations and organisations } \\
\text { (e.g., cooperatives) }\end{array}$ \\
\hline & \multirow{2}{*}{$\begin{array}{l}\text { 4. Are energy "communities" } \\
\text { different from both the } \\
\text { intervention of the state and the } \\
\text { operation of the market? }\end{array}$} & $\begin{array}{l}\text { Yes, they are third-sector actors } \\
\text { (nonprofit motivations). The "motive" } \\
\text { of the action counts. We need a new } \\
\text { "civic culture" }\end{array}$ & $\begin{array}{l}\text { Favour nonprofit actors (e.g., } \\
\text { exclusive eligibility for grants } \\
\text { and subsidies) }\end{array}$ \\
\hline & & $\begin{array}{l}\text { No, they are part of the private sector } \\
\text { (any kind of motivation). The "nature" } \\
\text { of the action counts. We need a new } \\
\text { "entrepreneurial culture" }\end{array}$ & $\begin{array}{c}\text { Favour voluntary actions and } \\
\text { endeavours, whatever they } \\
\text { may be }\end{array}$ \\
\hline
\end{tabular}

The conclusion is that there is no single interpretation for either the idea of distributed energy or that of energy communities. Instead, diverse interconnections and inevitable trade-offs emerge (as shown in Figure 2).

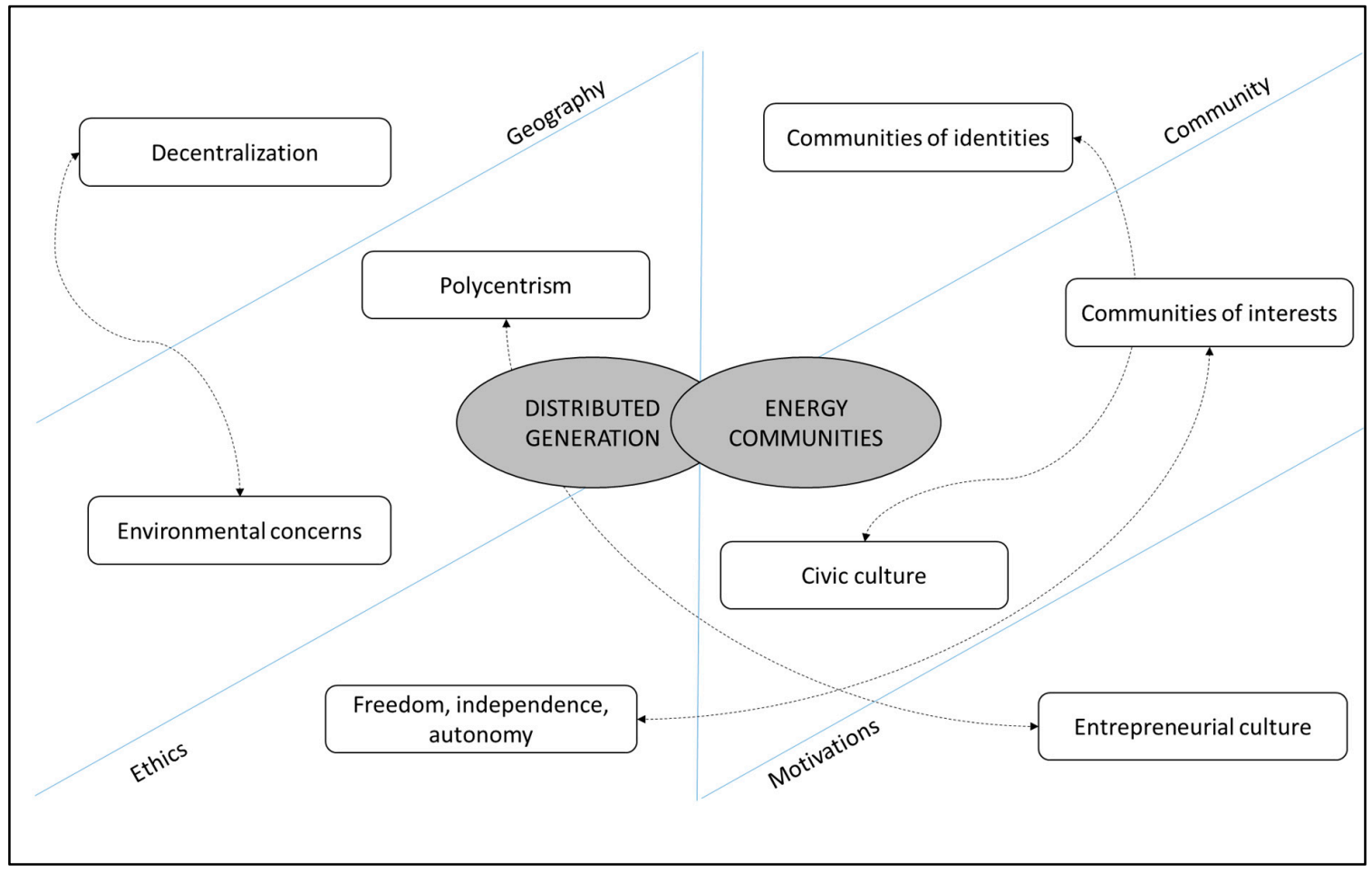

Figure 2. Contrasts and linkages. 
In particular, shifting emphasis from one feature or aspect to another can drastically alter what policies are needed to foster the creation of energy communities (some measures could indeed favour some community arrangements, while hampering others) and of a distributed energy production scenario (some measures could merely favour decentralisation, whilst others could favour polycentrism).

At this point in the debate, we therefore believe it beneficial (see also $[74,103,104]$ ) to highlight mainly the differences - values, perspectives, strategies - rather than insist on similarities, thereby acknowledging that there is no policy able to simultaneously satisfy the many values and aspirations at stake. It will therefore be necessary to concentrate research and discussion above all on unavoidable trade-offs.

Author Contributions: Conceptualisation, S.M.; Methodology, V.A. and A.B.; Investigation, S.M., V.A. and A.B.

Funding: This research received no external funding and the APC was funded by the Department of Innovation, Research and University of the Autonomous Province of Bozen/Bolzano (Italy).

Acknowledgments: The authors thank the Department of Innovation, Research and University of the Autonomous Province of Bozen/Bolzano for covering the Open Access publication costs.

Conflicts of Interest: The authors declare no conflict of interest.

\section{References}

1. European Commission. COM (2014) 15. A Policy Framework for Climate and Energy in the Period from 2020 to 2030. 2014. Available online: https:/eur-lex.europa.eu/legal-content/EN/ALL/?uri=CELEX\% 3A52014DC0015 (accessed on 13 June 2019).

2. United Nations. Transforming Our World: The 2030 Agenda for Sustainable Development. 2015. Available online: https://sustainabledevelopment.un.org/post2015/transformingourworld (accessed on 10 December 2018).

3. Denis, G.S.; Parker, P. Community Energy Planning in Canada: The Role of Renewable Energy. Renew. Sustain. Energy Rev. 2009, 13, 2088-2095. [CrossRef]

4. Klein, S.J.W.; Coffey, S. Building a sustainable energy future, one community at a time. Renew. Sustain. Energy Rev. 2016, 60, 867-880. [CrossRef]

5. Rodríguez-Molina, J.; Martínez-Núñez, M.; Martínez, J.F.; Pérez-Aguiar, W. Business models in the smart grid: Challenges, opportunities and proposals for prosumer profitability. Energies 2014, 7, 6142-6171. [CrossRef]

6. Bellekom, S.; Arentsen, M.; van Gorkum, K. Prosumption and the distribution and supply of electricity. Energy Sustain. Soc. 2016, 6, 22. [CrossRef]

7. European Commission Proposes New Rules for Consumer Centred Clean Energy Transition. Available online: https://ec.europa.eu/energy/en/news/commission-proposes-new-rules-consumer-centred-cleanenergy-transition (accessed on 10 December 2018).

8. European Commission. COM (2016) 861 Final/2. Proposal for a Regulation of the European Parliament and of the Council on the Internal Market for Electricity (Recast). 2016. Available online: http://eur-lex.europa. eu/legal-content/EN/HIS/?uri=CELEX\%3A52016PC0861 (accessed on 13 June 2019).

9. Koirala, B.P.; Koliou, E.; Friege, J.; Hakvoort, R.A.; Herder, P.M. Energetic communities for community energy: A review of key issues and trends shaping integrated community energy systems. Renew. Sustain. Energy Rev. 2016, 56, 722-744. [CrossRef]

10. REScoop Project 20-20-20. Best Practices. Report I. Available online: https://www.rescoop.eu (accessed on 10 December 2018).

11. Sioshansi, F. Innovation, Disruption and the Utility Business Model. 2017. Available online: https: //reneweconomy.com.au/innovation-disruption-and-the-utility-business-model-62549/ (accessed on 10 December 2018).

12. Bulkeley, H.; Broto, V.; Maassen, A. Low-carbon Transitions and the Reconfiguration of Urban Infrastructure. Urban Stud. 2014, 51, 1471-1486. [CrossRef]

13. Lane, M.B.; McDonald, G. Community-based environmental planning: Operational dilemmas, planning principles and possible remedies. J. Environ. Plan. Manag. 2005, 48, 709-731. [CrossRef] 
14. Walker, G.; Hunter, S.; Devine-Wright, P.; Evans, B.; Fay, H. Harnessing Community Energies. Explaining and Evaluating Community-Based Localism in Renewable Energy Policy in the UK. Glob. Environ. Politics 2007, 7, 64-81. [CrossRef]

15. Walker, G.; Devine-Wright, P. Community Renewable Energy: What Should It mean. Energy Policy 2008, 36, 497-500. [CrossRef]

16. Seyfang, G.; Park, J.J.; Smith, A. A thousand flowers blooming? An examination of community energy in the UK. Energy Policy 2013, 61, 977-989. [CrossRef]

17. Coles, A.M.; Piterou, A.; Genus, A. Sustainable Energy Projects and the Community: Mapping Single-Building Use of Microgeneration Technologies in London. Urban Stud. 2016, 53, 1869-1884. [CrossRef]

18. Moroni, S.; Alberti, V.; Antoniucci, V.; Bisello, A. Energy Communities in a Distributed Energy Scenario: Four Different Kinds of Community Arrangements. In Smart and Sustainable Planning for Cities and Regions; Bisello, A., Vettorato, D., Laconte, P., Costa, S., Eds.; Springer: Cham, Switzerland, 2018; pp. 429-437.

19. Moroni, S.; Alberti, V.; Antoniucci, V.; Bisello, A. Energy communities in the transition to a low-carbon future: A taxonomical approach and some policy dilemmas. J. Environ. Manag. 2019, 236, 45-53. [CrossRef] [PubMed]

20. Hicks, J.; Ison, N. An exploration of the boundaries of 'community' in community renewable energy projects: Navigating between motivations and context. Energy Policy 2018, 113, 523-534. [CrossRef]

21. Bristow, G.; Cowell, R.; Munday, M. Windfalls for whom? The evolving notion of 'community' in community benefit provisions from wind farms. Geoforum 2012, 43, 1108-1120. [CrossRef]

22. Aiken, G.T.; Middlemiss, L.; Sallu, S.; Hauxwell-Baldwin, R. Researching climate change and community in neoliberal contexts: An emerging critical approach. WIREs Clim. Chang. 2017, 8, 1-14.

23. Abbassa la bolletta. Available online: https://www.altroconsumo.it/gruppoacquisto/abbassalabolletta/ (accessed on 10 December 2018).

24. Retenergie. Available online: http://www.retenergie.it/andhttps://www.enostra.it/ (accessed on 10 December 2018).

25. Comunità Solare di Casalecchio di Reno. Available online: http://www.emiliaromagnastartup.it/it/innovative/ imprese/comunit-solare-locale (accessed on 10 December 2018).

26. SEV/Südtiroler Energieverband. Available online: http://www.sev.bz.it (accessed on 10 December 2018).

27. Solardachbörse. Available online: http://www.solardachboerse.de (accessed on 10 December 2018).

28. Gorran High Lanes. Available online: https://communitypowercornwall.coop/cornwalls-first-communityowned-renewable-energy-co-operative-launches-share-issue/ (accessed on 10 December 2018).

29. Samsø Island. Available online: http://energiakademiet.dk/enandhttp://www.h2020smile.eu/the-islands/ samso-denmark/ (accessed on 10 December 2018).

30. Highlands Ranch Community Association. Available online: http://www.hrcaonline.org (accessed on 10 December 2018).

31. Kauai Island Utility Cooperative. Available online: http://website.kiuc.coop/andhttps://www.grovefarm. com/about-us (accessed on 10 December 2018).

32. Moroni, S.; Tricarico, L. Distributed energy production in a polycentric scenario: Policy reforms and community management. J. Environ. Plan. Manag. 2018, 61, 1973-1993. [CrossRef]

33. Green, R.; Staffell, I. "Prosumage" and the British Electricity Market'. Econ. Energy Environ. Policy 2017, 6, 33-49. [CrossRef]

34. Akorede, M.F.; Hizam, H.; Pouresmaeil, E. Distributed energy resources and benefits to the environment. Renew. Sustain. Energy Rev. 2010, 14, 724-734. [CrossRef]

35. Méndez Quezada, V.H.M.; Abbad, J.R.; Roman, T.G.S. Assessment of energy distribution losses for increasing penetration of distributed generation. IEEE Trans. Power Syst. 2006, 21, 533-540. [CrossRef]

36. Dortolina, C.A.; Nadira, R. The loss that is unknown is no loss at all: A top-down/bottom-up approach for estimating distribution losses. IEEE Trans. Power Syst. 2005, 20, 1119-1125. [CrossRef]

37. Dorer, V.; Weber, A. Energy and $\mathrm{CO}_{2}$ emissions performance assessment of residential micro-cogeneration systems with dynamic whole-building simulation programs. Energy Convers. Manag. 2009, 50, 648-657. [CrossRef]

38. Shaw, R.; Attree, M.; Jackson, T.; Kay, M. The value of reducing distribution losses by domestic load-shifting: A network perspective. Energy Policy 2009, 37, 3159-3167. [CrossRef] 
39. Tong, Z.; Dong, Z.; Ashton, T. Analysis of electric field influence on buildings under high-voltage transmission lines. IET Sci. Meas. Technol. 2016, 10, 253-258. [CrossRef]

40. Leitgeb, N. Limiting electric fields of HVDC overhead power lines. Radiat. Environ. Biophys. 2014, 53, 461-468. [CrossRef] [PubMed]

41. Dunn, S. Micropower: New variable in the energy-environment-security equation. Bull. Sci. Technol. Soc. 2002, 22, 72-86. [CrossRef]

42. Bronin, S.C. Curbing energy sprawl with microgrids. Conn. Law Rev. 2010, 43, 547-584.

43. Warren, G.S. Vanishing power lines and emerging distributed generation. Wake For. J. Law Policy 2014, 4, 347-396.

44. Moroni, S.; Antoniucci, V.; Bisello, A. Energy Sprawl, Land Taking and Distributed Generation: Towards a Multi-Layered Density. Energy Policy 2016, 98, 266-273. [CrossRef]

45. Malerba, A.; Massimo, D.E.; Musolino, M.; Nicoletti, F.; De Paola, P. Post Carbon City: Building valuation and Energy Performance Simulation Programs. In New Metropolitan Perspectives; ISHT 2018; Smart Innovation, Systems and Technologies, 101; Calabrò, F., Della Spina, L., Bevilacqua, C., Eds.; Springer: Cham, Switzerland, 2018; pp. 513-521.

46. Scheer, H. Der Energethische Imperativ: 100 Prozent jetzt: Wie der vollständige Wechsel zuerneuerbaren Energien zu realisieren ist; Kunstmann: München, Germany, 2010.

47. Lowi, A.; Crews, C.W. Technology and Electricity. In The Half Life of Policy Rationales; Foldvary, F.E., Klein, D.B., Eds.; New York University Press: New York, NY, USA, 2003; pp. 161-183.

48. Jacobs, S.B. The Energy Prosumer. Ecol. Law Q. 2017, 43, 519-579.

49. Want to Go Off Grid? It Might Be Illegal in Your City. Available online: https://www.primalsurvivor.net/offgrid-illegal/ (accessed on 10 December 2018).

50. Is It Legal to Live Off Grid? Available online: http://www.wildlaw.org/environmental-law/legal-live-off-grid/ (accessed on 10 December 2018).

51. Off Grid Living Is Illegal! Sort of ... . Available online: https://offgridworld.com/off-grid-living-is-illegalsort-of/ (accessed on 10 December 2018).

52. Is It Illegal to Live Off the Grid? Available online: https://www.thealternativedaily.com/illegal-to-live-off-grid/ (accessed on 10 December 2018).

53. Lowi, A.; MacCallum, S. Community technology: Liberating community development. In Cities and Private Planning; Moroni, S., Andersson, D., Eds.; Edward Elgar: Cheltenham, UK, 2014; pp. 106-134.

54. Kaundinya, D.P.; Balachandra, P.; Ravindranath, N.H. Grid-connected versus stand-alone energy systems for decentralized power-A review of literature. Renew. Sustain. Energy Rev. 2009, 13, 2041-2050. [CrossRef]

55. El Bassam, N.; Maegaard, P.; Lawton Schlichting, M. Distributed Renewable Energies for Off-Grid Communities; Elsevier: Amsterdam, The Netherlands, 2013.

56. Foldvary, F.E.; Hammer, E.J. How advances in technology keep reducing interventionist policy rationales. Technol. Soc. 2016, 47, 16-24. [CrossRef]

57. Antoniucci, V.; Marella, G. The influence of building typology on the economic feasibility of urban developments. Int. J. Appl. Eng. Res. 2017, 12, 4946-4954.

58. Canesi, R.; Marella, G. Residential construction costs: An Italian case study. Int. J. Appl. Eng. Res. 2017, 12, 2623-2634.

59. Asmus, P. Microgrids, Virtual Power Plants and Our Distributed Energy Future. Electr. J. 2010, $23,72-82$. [CrossRef]

60. Adil, A.M.; Ko, Y. Socio-technical evolution of decentralized energy systems: A critical review and implications for urban planning and policy. Renew. Sustain. Energy Rev. 2016, 57, 1025-1037. [CrossRef]

61. Wiseman, H.J.; Bronin, S.C. Community-scale renewable energy. San Diego J. Clim. Energy Law 2013, 14, 165-194.

62. Doci, G.; Vasileiadou, E. 'Let's do it ourselves'. Individual motivations for investing in renewable at community level. Renew. Sustain. Energy Rev. 2015, 49, 41-50. [CrossRef]

63. Regalgid. Available online: http://www.regalgrid.com/en/snocu (accessed on 10 December 2018).

64. Ectogrid. Available online: http://ectogrid.com (accessed on 10 December 2018).

65. van der Horst, D. Social Enterprise and Renewable Energy: Emerging Initiatives and Communities of Practice. Soc. Enterp. J. 2008, 4, 171-185. [CrossRef] 
66. Tricarico, L. Community action: Value or instrument? An ethics and planning critical review. J. Archit. Urban. 2017, 41, 214-226. [CrossRef]

67. Herbes, C.; Brummer, V.; Rognli, J.; Blazejewski, S.; Gericke, N. Responding to policy change: New business models for renewable energy cooperatives-Barriers perceived by cooperatives' members. Energy Policy 2017, 109, 82-95. [CrossRef]

68. Süsser, D.; Kannen, A. Renewables? Yes, please!: Perceptions and assessment of community transition induced by renewable-energy projects in North Frisia. Sustain. Sci. 2017, 12, 563-578. [CrossRef]

69. Hepburn Wind. Available online: https://www.hepburnwind.com.au/about/ (accessed on 10 December 2018).

70. Walker, G.; Devine-Wright, P.; Hunter, S.; High, H.; Evans, B. Trust ad community: Exploring the meanings, context and dynamics of community renewable energy. Energy Policy 2010, 38, 2655-2663. [CrossRef]

71. Parkhill, K.A.; Shirani, F.; Butler, C.; Henwood, K.L.; Groves, C.; Pidgeon, N.F. 'We are a community [but] that takes a certain amount of energy': Exploring shared visions, social action, and resilience in place-based community-led energy initiatives. Environ. Sci. Policy 2015, 53, 60-69. [CrossRef]

72. Islar, M.; Busch, H. 'We are not in this to save the polar bears!'-The link between community renewable energy development and ecological citizenship. Innov. Eur. J. Soc. Sci. Res. 2016, 29, 303-319. [CrossRef]

73. Eadson, W. State enrolment and energy-carbon transitions: Syndromic experimentation and atomisation in England. Environ. Plan. C Gov. Policy 2016, 34, 1612-1631. [CrossRef]

74. Aiken, G. Community Transitions to Low Carbon Futures in the Transition Towns Network (TTN). Geogr. Compass 2012, 6, 89-99. [CrossRef]

75. Bisello, A.; Grilli, G.; Balest, J.; Stellin, G.; Ciolli, M. Co-benefits of smart and sustainable energy district projects: An overview of economic assessment methodologies. Green Energy Technol. 2017, 127-164. [CrossRef]

76. Hatzl, S.; Seebauer, S.; Fleiß, E.; Posch, A. Market-based vs. grassroots citizen participation in initiatives in photovoltaics: A qualitative comparison of niche development. Futures 2016, 78, 57-70. [CrossRef]

77. Seyfang, G.; Smith, A. Grassroots Innovations for Sustainable Development: Towards a New Research and Policy Agenda. Environ. Politics 2007, 16, 584-603. [CrossRef]

78. Frantzeskaki, N.; Avelino, F.; Loorbach, D. Outliers or Frontrunners? Exploring the (Self-) Governance of Community-Owned Sustainable Energy in Scotland and the Netherlands. In Renewable Energy Governance; Michalena, E., Hills, J.M., Eds.; Springer: Berlin, Germany, 2013; pp. 101-116.

79. Beito, D.T.; Gordon, P.; Tabarrok, A. Toward a Rebirth of Civil Society. In The Voluntary City; Beito, D.T., Gordon, P., Tabarrok, A., Eds.; The University of Michigan Press: Ann Arbor, MI, USA, 2002.

80. Bull, M. Challenging Tensions: Critical, Theoretical and Empirical Perspective on Social Enterprise. Int. J. Entrepreneurial Behav. Res. 2008, 14, 268-275. [CrossRef]

81. Cato, N.S.; Arthur, L.; Keenoy, T.; Smith, R. Entrepreneurial energy: Associative entrepreneurship in the renewable energy sector in Wales. Int. J. Entrepreneurial Behav. Res. 2008, 14, 313-329. [CrossRef]

82. Picciarello, A.; Vergara, C.; Reneses, J.; Frias, P.; Sölder, L. Electricity Distribution Tariffs and Distributed Generation: Quantifying Cross-Subsidies from Consumers to Prosumers. Util. Policy 2015, 37, $23-33$. [CrossRef]

83. Jain, S.; Kalambe, S.; Agnihotri, G.; Mishra, A. Distributed Generation Deployment: State-of-the-Art of Distribution System Planning in Sustainable Era. Renew. Sustain. Energy Rev. 2017, 77, 363-385. [CrossRef]

84. Zibelman, A. Introduction. In Innovation and Disruption at the Grid's Edge; Sioshansi, F.P., Ed.; Elsevier: Amsterdam, The Netherlands, 2017; pp. xxix-xxxiii. [CrossRef]

85. Moroni, S. Land-Use Regulation for the Creative City. In Handbook of Creative Cities; Andersson, D.E., Andersson, A.E., Mellander, C., Eds.; Edward Elgar: Cheltenham, UK, 2011; pp. 343-364.

86. Hain, J.J.; Ault, G.W.; Galloway, S.J.; Cruden, A.; McDonald, J.R. Additional renewable energy growth through small-scale community orientated energy policies. Energy Policy 2005, 33, 1199-1212. [CrossRef]

87. Kellett, J. Community-Based Energy Policy: A Practical Approach to Carbon Reduction. J. Environ. Plan. Manag. 2007, 50, 381-396. [CrossRef]

88. Hall, S.; Foxon, T.J.; Bolton, R. Financing the civic energy sector: How financial institutions affect ownership models in Germany and the United Kingdom. Energy Res. Soc. Sci. 2016, 12, 5-15. [CrossRef]

89. Mazzucato, M.; Semieniuk, G. Financing renewable energy: Who is financing what and why it matters. Technol. Forecast. Soc. Chang. 2018, 127, 8-22. [CrossRef] 
90. Brandoni, C.; Polonara, F. The role of municipal energy planning in the regional energy-planning process. Energy 2012, 48, 323-338. [CrossRef]

91. Comodi, G.; Cioccolanti, L.; Polonara, F.; Brandoni, C. Local authorities in the context of energy and climate policy. Energy Policy 2012, 51, 737-748. [CrossRef]

92. McGuirk, P.; Dowling, R.; Bulkeley, H. Repositioning urban governments? Energy efficiency and Australia's changing climate and energy governance regimes. Urban Stud. 2014, 51, 2717-2734. [CrossRef]

93. Engelken, M.; Römer, B.; Drescher, M.; Welpe, I. Transforming the energy system: Why municipalities strive for energy self-sufficiency. Energy Policy 2016, 98, 365-377. [CrossRef]

94. Brunetta, G.; Moroni, S. Contractual Communities in the Self-Organising City; Springer: Dordrecht, The Netherlands, 2011.

95. Moroni, S. Towards a General Theory of Contractual Communities. In Cities and Private Planning; Andersson, D., Moroni, S., Eds.; Edward Elgar: Cheltenham, UK, 2014; Volume 2011, pp. 38-65.

96. Della Valle, N.; Bisello, A.; Balest, J. In search of behavioural and social levers for effective social housing retrofit programs. Energy Build. 2018, 177, 91-96. [CrossRef]

97. Jenner, S.; Groba, F.; Indvik, J. Assessing the strength and effectiveness of renewable electricity feed-in tariffs in European Union countries. Energy Policy 2013, 52, 385-401. [CrossRef]

98. Cointe, B.; Nadaï, A. Feed-In Tariffs in the European Union; Palgrave Macmillan: London, UK, 2018. [CrossRef]

99. Chomat, G.; Lückge, H.; Morelle, N. Towards Renewable Alps. A progress report for the period 2015-2016. Permanent Secretariat of the Alpine Convention. 2017. Available online: http:/www.alpconv.org/en/ publications/alpine/Documents/Towards\%20Renewable\%20Alps\%202017.pdf (accessed on 13 June 2019).

100. Huybrechts, B.; Creupelandt, D.; Vansintjan, D. Networking Renewable Energy Cooperatives-The experience of the European Federation REScoop.eu. In Handbuch Energiewende und Partizipation; Holstenkamp, L.L., Radtke, J., Eds.; Springer: Wiesbaden, Germany, 2018.

101. Energy Outreach Colorado. Available online: http://www.energyoutreach.org/grants/facility-energyefficiency (accessed on 10 December 2018).

102. State Grant Program|Open Energy Information-OpenEI. Available online: https://openei.org/wiki/State_ Grant_Program (accessed on 10 December 2018).

103. West, J.; Bailey, I.; Winter, M. Renewable energy policy and public perceptions of renewable energy: A cultural theory approach. Energy Policy 2010, 38, 5739-5748. [CrossRef]

104. Lawhon, M.; Murphy, J.T. Socio-technical regimes and sustainability transitions: Insights from political ecology. Prog. Hum. Geogr. 2012, 36, 354-378. [CrossRef] 